FINAL PERFORMANCE REPORT; GRANT \# DE-FG05-87ER60572

INSTITUTION; Duke University, Durham, North Carolina, 27706

TITLE: "Effects of pesticides on crab cheliped regeneration"

Principal Investigator: John D. Costlow, Jr. , Ph.D. , Professor of Zoology, Duke University, Durham, North Carolina, 27706 (In residence, Duke University Marine Laboratory, Beaufort, N.C. 28516; retired 1991)

Research Associate: A.Clare, Ph.D., Duke University Marine Laboratory, Beaufort, N.C. , 28516.

\title{
SUMMARY OF RESULTS
}

Effects of pesticides on crab cheliped regeneration;

As indicated in the list of publications, the mud crab cheliped regeneration bioassay has proven to be a sensitive and reliable bioassay in studies of the potential sublethal effects of pesticides, including teratogenesis, spontaneous autotomy, and duration of the various stages of development. The assay has also been demonstated to be a useful indication of mortality associated with the impact of these chemicals of anthropogenic origin during the megalopal and early postlarval stages of development.

During the period of the Grant, four pesticides were tested using the cheliped regeneration bioassay technique. Two of these chemicals are identified as carbamate insecticides: e.g.. methomyl and carbofuran. Although carbofuran is approximately 5-6 times more toxic than methomyl, both compounds yield very similar results in terms of sublethal effects. Data for methomyl have been included in several publications from these studies (See PUBLICATIONS). Essentially methomyl in the $150-200 \mathrm{ppb}$ range of concentrations in sea water causes spontaneous autotomy of appendages of the larval stages exposed. Also, these concentrations resulted in prolonger development of several of the developmental stages and malformed regenerated appendatges if regeneration occurred. It is noteworthy that those animals which died in response to the insecticide did so at or about the time of the molt to the next stage of development in the life cycle of this marine/estuarine organism.

Prolonger larval development is consistent with methomyl serving as a substrate for

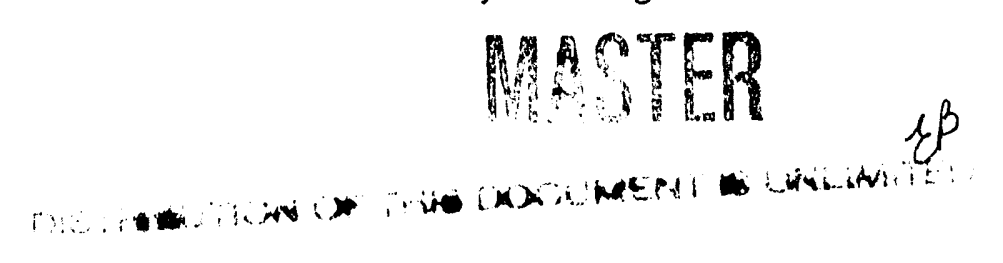


a mixed function oxygenase enzyme reponsible for catalyzing the metabolism of the molting hormone. Spontaneous autotomy of the chela (claw) of the megalopa, on the other hand, points to a nervous effect which could be anticipated since methomyl is an inhibitor of acetylocholinesterase. Consequently, this chemical is known to be a nerve poison. Malathion, another acetylocholinesterase inhibitor, had previously been identified to have the same effect (Bookhout and Monroe, 1977).

Although other studies have identified carbamate insecticides as having teratogenic effects on other organisms, we are unaware of previous reports that these chemicals acts as a teratogen. It has yet to be established whether the observed malformations of chela in developing crab larvae caused by methomyl may be reversible.

Two other pesticides have also been included in the current studies employing the cheliped regeneration bioassay. These included similar studies on a non-steroid molting hormone agonist, RH 5849 (1,2-dibenzoyl-1-tert-butylhydrazine). No effects on regeneration were observed when meglopa were maintained in concentrations ranging from $0.1-5.0 \mathrm{ppm}$. The herbicide Alachlor, however, was observed to have much the same effects as the carbamate insecticides but at much higher concentrations. Sublethal effects of alachlor were noted in concentrations of 4.0 10.0 ppm.

Morphology of regeneration in the telson of Limulus polyphemus;

A method for the large-scale culture of horseshoe crab larvae from eggs has been developed for further studies on regeneration (Clare et al, 1990). The first larval stage following hatching - the "trilobite larva" - does not possess a telson but subsequent stages do. Preliminary experiments determined that if a telson is ablated during the second instar, regeneration occurs during subsequent molts until the seventh instar when a fully formed telson is attained. The morphology of regeneration has been followed during these early postlarval stages at the ultrastructural level. The results of this study will serve as a baseline against which studies of regeneration in the presence of xenobiotics can be compared. The main findings of this study include the identification of two new types of "haemocytes" in addition to the previously described granular amoebocytes. Moreover, "haemocytes" apparently serve as pleuripotential cells and differentiate into nerve, muscle, and possibly "blood" vessels. The further development of techniques for the "in vitro' culture of haemocytes in the presence of xenobiotics should prove to be a sensitive approach for the study of teratogenic effects of a variety of compounds.

The preliminary results suggest that the process of regenertion in mud crab larvae is similar to that observed in the telson of Limulus. 
Effect of pesticides on duration of larval stages;

The experimental insecticide $\mathrm{RH} 5849$ has been further tested to determine if it will result in prolonging the duration of larval stages of the mud crab. Rhithropanopeus harrisii, a Brachyuran crab which we have found to be an excellent experimental animal for laboratory studies due to its considerable geographic distribution (Nova Scotia,Canada to Key West, Florida) and the high survival rate under controlled conditions in the laboratory $(85 \%)$. In this portion of the study, the definitice concentrations employed were: $0.0,0.1,1.0$, and $10.0 \mathrm{ppm}$. The two lowest concentrations induced premature molting when compared to the controls. Larvae in 10.0 ppm RH 5849 did not molt or feed and eventually died. It would appear that in the higher concentrations, premature apolysis results, leading to death of the organism. These effects are consistent with the action described by other authors working with insects (Wing, et al, 1988; Wing, 1988) and suggest that the ecysteroid receptors in crustaceans are similar to those described in insects.

\section{LITERATURE CITED}

Bookhout, C.G. and R.J.Monroe, 1977. Effects of malathion on the development of crabs, in Physiological Responses of Marine Biota to Pollutants, eds. F.J.Vernberg, A. Calabrese, F.P.Thurberg, and W. Vernberg, 3-19. New York, Academic Press

Wing, K.D., 1988. RH 5849, A nonsteroidal ecdysone agonist; effects on Drosophila cell line. Science 241: 467-469.

Wing, K.D., R.A.Slawecki, and G.R.Carlson, 1988. RH 5849, A nonsteroidal ecdysone agonist; effects on larval Lepidoptera. Science 241: 470-472.

\section{PUBLICATIONS FROM CURRENT GRANT;}

Bedair, H.M. and J.D.Costlow, Jr., 1989. Effects of the pyrethroid insecticide cypermethrin on the larval development of the mud crab Rhithropanopeus harrisii (Gould) . National Research Conference on Pesticides in the Aquatic Environment, Richmond, VA. (Abstract)

Costlow, J.D. and A.S.Clare, 1989. Testing for toxicity with various life stages of marine organisms. (Minerals Management Service, Workshop on Technical Specifications for Oil and Dispersants Toxicity Testing, New Orleans, January 1989; 7 pg.s

Clare, A.S. and J.D.Costlow,Jr., 1989. Effects of the insecticide methomyl on 
development and regeneration in the megalopa and juveniles of the mud crab, Rhithropanopeus harrisii (Gou!d). !n: Fosticides in Terrestrial and Aquatic Environments. Proceedings of a National Research Conference, D.L. Weigmann, ed. pp. 3-16.

Clare, A.S., G.Lumb, Clare, P.A. and J.D.Costlow,Jr., 1990. A morphological study of wound response and telson regeneration in postlarval Limulus polyphemus (L.). Invert. Reprod. Devel., 17: 77-87.

Clare, A.S., D.Rittschof, and J.D.Costlow,Jr., 1992. Effects of the nonsteroidal ecdysone mimic RH 5849 on larval crustaceans. J.Exp. Zoology, 262: 436-440.

Lumb, G., A.S.Clare, and J.D.Costlow, 1991. Cheliped regeneration in the megalopa of the mud crab, Rhithropanopeus harrisii (Gould). Invert. Reprod. and Devep., 20(2); 87-96.

\section{DISCLAIMER}

This report was prepared as an account of work sponsored by an agency of the United States Government. Neither the United States Government nor any agency thereof nor any of their employees, makes any warranty, express or implied, or assumes any legal liability or responsibility for the accuracy, completeness, or usefulness of any information, apparatus, product, or process disclosed, or represents that its use would not infringe privately owned rights. Reference herein to any specific commercial product, process, or service by trade name, trademark, manufacturer, or otherwise does not necessarily constitute or imply its endorsement, recommerdation, or favoring by the United States Government or any agency thereof. The views and opinions of authors expressed herein do not necessarily state or reflect those of the United States Government or any agency thereof. 

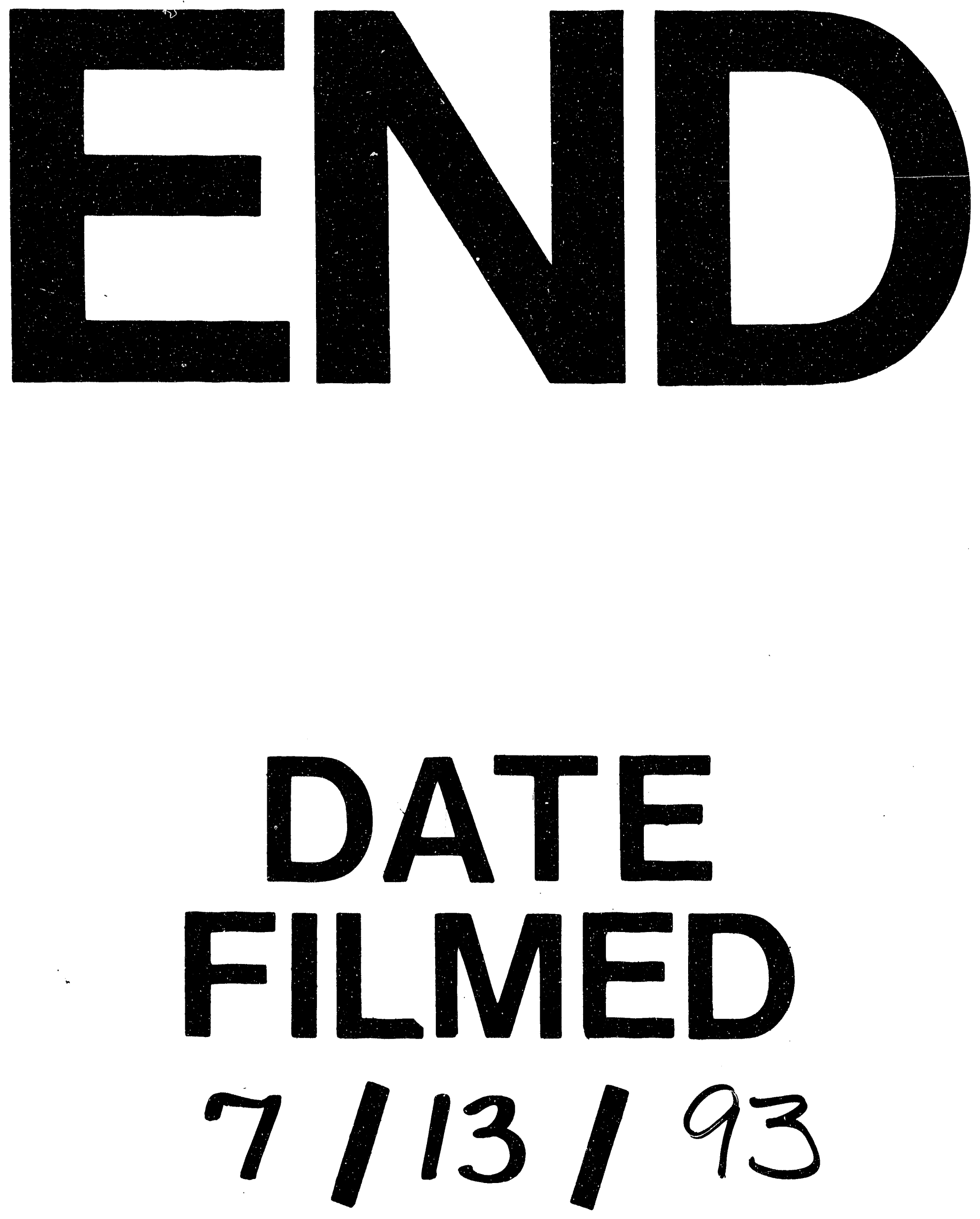
